\title{
Complaint Management and Suppliers' Engagement in Long-term Relationships: A Conceptual Model based on Fairness Theory
}

\author{
Tahereh Zaefarian (Corresponding author) \\ Dept. of Industrial Engineering, Khatam Institute of Higher Educations \\ No. 861, West Ferdous Blvd, Tehran- 14837, Iran \\ Tel: 98-919-2108346Ｅ-mail: tahereh.zaefarian@gmail.com
}

Reza Zaefarian

Dep. of Entrepreneurship, University of Tehran

Enghelab Street, Tehran, Iran

Tel: 98-21-8822-5000Ｅ-mail: rzaefarian@gmail.com

Received: April 5, 2012 Accepted: April 18, 2012 Published: June 13, 2012

doi:10.5296/ber.v2i1.1594 URL: http://dx.doi.org/10.5296/ber.v2i1.1594

\begin{abstract}
Although the importance of buyer-supplier relationship has long been focused in literature of business and management, little is known about complaint management and its impacts in the context of business-to-business. This study tries to address this gap in the literature by investigating the impacts of complaint management and perceived fairness on the relationship of suppliers' long-term orientation towards the buyer firm.

Based on the profound review of the literature, a conceptual model will be developed and hypotheses will be suggested. We use fairness theory as the theoretical grounding for this research and develop a conceptual model that suggests examining the effects of fairness (i.e. procedural, distributive, interaction, and information justice) on trust, commitment and conflict. We further suggest examining the impact of these relational characteristics on the long-term orientation, cooperation, and opportunism as well as examining the moderating role of relationship quality on the link between perceived fairness and relational characteristics.
\end{abstract}

Keywords: Fairness theory, Business to business relationship, long-term orientation 


\section{Introduction}

Business relationships form the fundamental building blocks of business and economics in the twenty-first century. Many scholars have studied business relationships to determine factors make them more effective and those make them ineffective. Fairness theory - a significant topic in business relationships concept- is closely related to consumer relationship. Researchers have identified the antecedents and consequences of misconduct and complaint management on the final consumers' behavior such as continuity of the relationship, word of mouth and etc.

This research aims to study the impact of complaint management on suppliers' attitude in long term in business-to-business context. We focus on behavioral consequence of unequally treating various suppliers in business-to-business settings. Not considering the consequence effects on suppliers, the strategic changes are made by a buyer -to increase the revenue- may have several concurrent and consecutive effects on them. It means some of them will be satisfied and others will be dissatisfied. Suppliers, whom are dissatisfied, will react in one of two following ways: first; they latter may cut off the relationship and seek for new business partners or second; continue to have relationship with the firm, even though they are dissatisfied with consequences, because they have no more choice to replace. Hence, they will presumably change their behavior athwart of their promise to the firm.

The theoretical background for this study is explained in the following.

\section{Literature Review}

\subsection{Perceived fairness}

Homans (1961) defined fairness theory as an attempt to have justice in a business environment which is consists of outcome (due to considered fairness), investments and inputs. One of earliest studies in fairness theory goes to Homans (1961) which believed that customers consider fairness in any types of exchange. So, they definitely assess the amount of perceived fairness in comparison with their contributions in the exchange. As such, Bowen et at. (1999) developed fairness theory in organizational behavior and represented that preserving customers even in a small scale will be resulted in high profitability.

Fairness helps firms to sustain their customers and find satisfactory results (Bowen et al., 1999; Saxby et al., 2000). Hocutt et al. (1997) studied the effects of perceived fairness on complaint management. The results revealed that perceived fairness can have negative effects on complaint management. Tax et al. (1998) considered the effects of fairness on each of trust and commitment, and found that fairness have a positive effects on both of them.

Some researchers studied the relationship between fairness, satisfaction and loyalty (Clemmer and Schneider, 1996; Holbrook and Kulik, 2001). Others showed that enhancing perception of fairness in a business process will reduces the level of disruption in integration efforts (Schweiger and DeNisi, 1991; Steensma and Van Milligen, 2003). Moreover, fairness theory has been applied in both positive and negative changes on perceived fairness of outcome (Writz et al., 2003). 
This study focuses on those suppliers who believe that the firm treats in an equal perceived fairness and those underline the firm treat in an unequal manner. The effects of fairness and its relationship by suppliers as well as its impact on each of trust, commitment and conflict will be considered in the proposed conceptual model.

\subsection{Procedural, interaction, distributive, and Informational Justice}

Justice is the starting point of appraising relationship quality between a firm and its customers. Creating stable relationships with customers as well as believing in security and justice by clients, corporations will be able to earn profit (Aurier and Siadou-Martin, 2007). Customers will easily accept outcomes if they have decision rules' control (Thibaut and Walker, 1975) or they believe suppliers have responsiveness and flexibility (Bitner et al., 1990).

The Justice literature is divided into four various types: procedural justice, interaction justice, distributive justice and informational justice (Colquitt et al., 2001). Procedural justice is defined as an effort to assure customers the procedures and the processes are based on fairness. To able them make decision easier than before (Greenberg, 1987; Lind and Tyler, 1988). Interaction justice focuses on the fairness perception of customers about the behavior of their social interactions (Homburg and Fürst, 2005) and covers different and complementary perspectives employee puts into a business relationship, including employee politeness, empathy and efforts (Smith et al., 1999; Tax et al., 1998). Distributive justice compares the outcomes achieved by customers with the inputs, and thus refers to the perceived fairness of tangible outcomes (Hoffman and Kelley, 2000; McColl-kennedy and Sparks, 2003; Homburg and Fürst, 2005). Finally, informational justice is clarified as an effort to justify decisions and procedures (Bies and Shapiro, 1988; Greenberg, 1993).

Aurier and Siadou-Martin (2007) examined the role of perceived justice in either service consumption or purchase experiences and found that although justice has direct effect on satisfaction, has indirect impacts on each of outcome, interaction and value. Considering independent and interactive effects of justice (procedural and informational ones) in integration of related acquisitions, Ellis et al. (2009) found that procedural justice critically effects on market positioning in an integration process, while the other one is a basic tool to attain market positioning gains.

The conceptual model encompasses the relationship between each of procedural justice and informational justice with perceived fairness in a buyer-supplier relationship which is the gap in the justice literature.

\subsection{Trust and Commitment}

Trust is defined as confidence of customers' reliability affects directly on outcomes and indirectly on commitment (Morgan and Hunt; 1994) and commitment is defined as customer's wish to have a valuable relationship (Moorman et al., 1992).

Regarding Morgan and Hunt (1994), one of the fundamental elements of exchange performance is the amount of trust or commitment customers have toward a seller. They developed a social exchange-based theory asserts that commitment and trust are the most 
significant "keys" to promote effectiveness, efficiency and productivity of dyadic relationships. They also found that commitment may enhances the financial performance. Using four years of longitudinal data, Palmatier et al. (2007) compared benefits of successful interorganizational relationship performance (commitment or trust, dependence, transaction cost economics and relation norms) and found that relationship specific investments and either commitment or trust are equally important for exchanging performance.

Personal trust is the most significant behavioral element affects on outcomes (Zaltman and Moorman, 1988). High level of trust decreases the formal control mechanisms and hence total transactions costs will be reduced (MacNeil 1980; Nooteboom et al., 1997). Where customers prefer to communicate with committed and trusted sellers, both trust and commitment will have positive effects on exchange performance and rational behaviors (Hibbard et al,. 2001). Hamel (1991) found that if parties have high level of trust, it may cause them search the necessaries less than the time there is no trust.

Relationship-specific investments between a supplier and a focal buyer can influence on commitment of the buyer toward the seller (Gilliland and Bello, 2002). Other factors have positive and significant impacts on the level of trust and commitments including information sharing (Mohr et al., 1996), dependency (Kumer et al., 1995) and idiosyncratic investment on the dyadic relationship between the them (Gassenheimer and Manolis; 2001). Through commitment enhancement, value systems will be converged and so, common identities of parties will be expanded (Gaertner, et al., 1996).

Scholars found that parties have more intention to share information if they believe they are not either exploited or harmed (Jap 1999, 2001; Morgan and Hunt 1994) and leave short-time gains in case the other party has high amount of cost (Axelrod 1984).

The conceptual model will suggest examining the effect of fairness (i.e. procedural, distributive, interaction, and information justice) on each of trust and commitment in a buyer-supplier relationship which is the gap in the trust and commitment literature.

\subsection{Cooperation and Conflict}

Jap and Ganesan (2000) have examined the relationship between cooperation and successful goal achievement as well as the relationship between conflict and lucrative goal achievement. Powerful interfirm relationships directly increase both sale and profit (Palmatier et al., 2006), decrease cost and improve innovation because there is higher cooperation and less conflict. In other words, higher cooperation reduce the amount of conflict between buyer and seller (Cannon and Homburg 2001; Rindfleisch and Moorman 2001).

Dependence and power structure in a buyer-supplier relationship can influences the level of inter-organizational conflict and then affects on performance (Gundlach and Cadotte 1994). The relationship among conflict, cooperative norms and focal firm performance has been examined in the literature (Bucklin and Sengupta 1993). Cannon et al. (2000) found that the more strength of relational norms, the more effects on the level of cooperative behavior and relationship performance. 
To cover the gap in the literature and consistent with the previous studies, the conceptual model examines the relationship between perceived fairness and conflict in business to business context.

\subsection{Long-term orientation}

Supplier will definitely lose when a buyer's perception from business outcome get dissatisfactory. So, it leads to the buyer-supplier relationship interruption and future negative behaviors of suppliers (Kelley et al., 1993).

Existing strong relationship between a buyer and its suppliers, suppliers tend to support this relationship in long term, even if they lose in short term (Ha and Jang, 2009; Ok et al., 2005). In fact, the level of customer satisfaction and their future behavioral intentions depend on their perceptions to whether they are treated fairly (McColl-Kennedy and Sparks, 2003).

Ha and Jang (2009) studied the role of relationship quality in justice and customer long-term orientation. If firms be able to decrease customer defections rates by $5 \%$, they can rapidly increase their profits up to 85\% (Reichheld and Sasser, 1990). In hospitality industry, decreasing customer defection rate from $20 \%$ to $10 \%$ cause increasing the average life from 5 to 10 years and therefore, this cause profit growth (Orilio, 2007).

Some researchers believed that trust is an expectation regarding a partner's dependability (Blau 1964; Pruitt 1981; Rotter 1967) and some others insist that trust is a behavioral intention (Coleman 1990; Deutsch 1962; Giffin 1967; Schlenker et al., 1973).

We further suggest examining the impact of these relational characteristics (trust, commitment and conflict) on long-term orientation.

\subsection{Opportunism}

Opportunism is defined as one of the significant behavioral consequences in buyer-supplier relationships (Williamson, 1975). Opportunism behavior of seller is a self-interest seek for dishonesty (John, 1984) and for supports which have negative influence on customer's trust toward seller (Williamson, 1975). Breach of contract, lying, incorrect information, and fraud are examples of opportunism (John, 1984).

Grayson and Ambler (1999) studied the relationship between opportunism and trust. The outcomes showed that opportunism (self-seeking behavior) may results in less effectiveness of high-trust relationships. Some researchers believed that mutual dependence between seller and buyer will decrease their opportunistic tendency (Heide and John 1988; Parkhe 1993). Gundlach et al., (1995) studied the impact of opportunistic on the appearance of relational sense. They found that opportunistic behaviors negatively affect on appearance the relational feelings.

We further suggest examining the impact of these relational characteristics (trust, commitment and conflict) on opportunism in business to business context.

\subsection{Relationship Quality}


Relationship quality is defined as customer's intuition and appraisal of how relationship satisfies expectation, predictions goals and customer needs (Jarvelin and Lehtinen, 1996; Kim and Cha, 2002).

Some researchers studied the effects of trust on relationship quality. They argued that trust can be found as a characteristic of relationship quality together with opportunism and satisfaction (Dwyer and Oh 1987; Crosby et al., 1990). Others believed that high relationship quality helps customers to be hopeful in firm's future performance (Wong and Sohal, 2002). The most significant goal of a relationship is to connect buying and selling activities of buyers and suppliers, respectively; such as $R \& D$, quality control, marketing and so on. If the effectiveness of the relationship satisfies both customer and supplier, the relationship will be well performed (Selnes and Sallis, 2003). Kalwani and Narayandas (1995) studied the effects of relationship between customers and manufacturers in long-term relationship and found that this kind of relationship affects both inventory levels and cost control. Therefore, the overall cost will decrease. Lower cost means customers have to pay lower prices.

High level of relationship quality is connected with high level of trust and commitment, where it causes higher level of customer retention (Sheaves and Barnes, 1996). In other word, having trust and commitment, customers need future benefits like confidence and economic advantages, where confidence decreases risk and also economic advantages reduces discounts (Wong and Sohal, 2002).

The conceptual model suggests that relationship quality can play a moderating role for the links between perceived fairness and each of trust, commitment and conflict. Indeed, the higher the quality of the relationship, the more rigorous is the link between perceived fairness and trust, commitment and conflict in a buyer-supplier relationship.

\section{Suppliers Behavior and Fairness Theory}

This study considers behavioral consequence of unequally treating with various suppliers in business to business relationships. Although firms have different business strategies for treat with their suppliers, they may change their macro-strategies to achieve maximum revenue. Hence, they behave in a different way than before with their suppliers. Change in strategies towards relationship may happen as a result of change in pricing strategies, change in capacity strategies, and so on.

Applying new strategies, suppliers will have different perceptions regarding the way they have been treated: some believes in gaining benefit and others have faith in lost their benefits. In this research, we look at both positive and negative perception of suppliers, those who have positive impression and those who have negative impression from new strategies.

The first group is satisfied from the consequence and so continues their relationship with focal buyer and tries to be more cooperative. The second group may perceive this change as no fair to their business. So, this conflict of interests will be resulted in negative behavioral intentions: they may cut the relationship and seek for new business partners or continue to have relationship with firm, although they are dissatisfied with consequences. They change their behavior and do not supply as promised, because they have no other proper choice to 
replace. This will be resulted in penalty fees defined by firm which is the starting point of rebellion for suppliers.

Fairness and justice (procedural justice, interaction justice, distributive justice, and informational justice) are used to study the effects of having different strategies in a business relationship. If suppliers do not believe in fairness in their relationship with firm, it may causes losing trust toward it. In addition, it diminishes its commitment and therefore it will cause conflict between two-parties.

Each of trust, commitment and conflict may have influence on cooperation between suppliers and firm. The higher conflicts and lower trust and commitment can bring about cooperation interruption. In contrast, the lower conflicts and higher trust and commitment may encourage more powerful business relationship. It is possible for suppliers do not interrupt the cooperation with firm, but they may show different behavioral intentions than before toward firm or in some situation show opportunism. Besides, relationship quality effects as a moderator on relationship between perceived fairness and each of trust, commitment and conflict indirectly.

\section{Conceptual Model and Hypotheses}

This model is based on perceived fairness of how each supplier groups is treated by firm (buyer). It is assumed that their perceptions have impact on some elements of relationships. In this part, we will describe the conceptual model and also defined hypotheses as follows. Figure1 illustrates the conceptual model and the hypotheses.

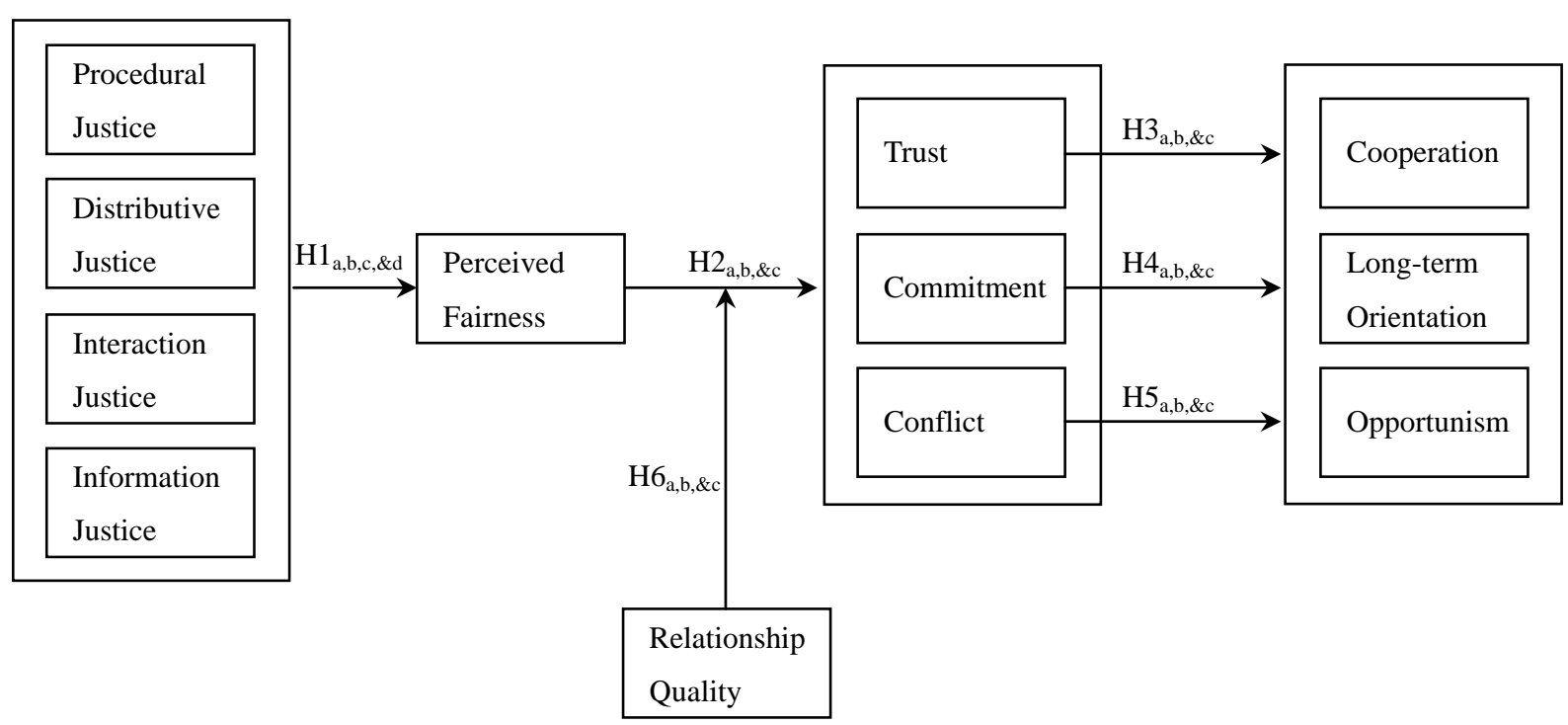

Figure 1. The Relationships and hypotheses

\subsection{Justice and perceived fairness}

Suppliers may do not believe in equal perceived fairness, while firm decide to make changes in their behaving strategies toward its total suppliers. Applying new strategies, suppliers may 
be divided to two groups. One group has a good feeling about new strategies and the second one has no good perception from perceived fairness equally.

Therefore, the first group who are satisfied with new strategies will continue to their relationships with firm. But, the second one may act in one of two following ways: First, they do not agree with perceived fairness. So, they interrupt the relationship and seek for new business partners. Second, although they are dissatisfied with consequence, they continue to have relationship with firm. Because they have no other proper choice to replace, but they believe the relationship of firm with its suppliers is not fair equally and so they do not supply in the best way. In this study, we consider the relationship fairness from aspect of procedural justice and informational justice.

In business to business relationships, both procedural justice and informational justice have significant effect on suppliers' perceived fairness. Although suppliers may not be satisfied with outcome, they certainly would believe that the firm did its best to respects the relationship, if the firm clarifies the procedure and required information in applying new strategies. Hence, the outcome will be acceptable for suppliers, despite the dissatisfactory consequence. Therefore, the effect of both procedural justice and informational justice on perceived fairness is not condonable. So, to examine the effects of justice on perceived fairness, this research proposes the following hypotheses.

H1 $1_{a}$ : The procedural justice has a direct positive effect on perceived fairness.

$H 1_{b}$ : The interaction justice has a direct positive effect on perceived fairness.

$H 1_{c}$ : The distributive justice has a direct positive effect on perceived fairness.

$H 1_{d}$ : The informational justice has a direct positive effect on perceived fairness.

\subsection{Perceived fairness and trust, commitment and conflict}

Aside from perceived fairness and justice, there are other characteristic in a business relationship such as trust, commitment and conflict. Giving sufficient information to suppliers cause they put more trust on firm. In addition, perceived fairness can effect on suppliers' commitment toward firm and they force themselves to undertake their responsibilities than firm. On the other hand, perceived fairness has impact on the level of conflict in the relationship between suppliers and firm.

Thus, to examine the effects of perceived fairness on each of trust, commitment and conflict, we hypothesize the following.

$H 2_{a, b}$ : The perceived fairness positively affects suppliers' (a) trust and (b) commitment.

$H 2_{c}$ : The perceived fairness negatively affects suppliers' conflict.

\subsection{Trust versus cooperation, behavioral intention and opportunism}

In B2B relationships, suppliers expect to have long-term cooperation with firm, which is resulted from having trust in their business relationship. If firm behave in a fair manner in relationship with each of its suppliers, which it causes more trust, it impresses suppliers' 
behavioral intentions and also they do not intend to cheat on firm and tendency to being opportunist.

In contrast, having no trust can interrupt current cooperation. Suppliers may have propensity to complaint or even tendency to use opportunities for cheat on. So, to examine the effects of trust on each cooperation, behavioral intention and opportunism, this research proposes the following hypotheses.

$H 3_{a, b}$ : The trust positively affects suppliers' (a) cooperation and (b) long-term orientation.

$H 3_{c}$ : The trust negatively affects suppliers' opportunism behaviour.

\subsection{Commitment versus cooperation, behavioral intention and opportunism}

More commitment may cause more long-term relationship. Furthermore, it can be resulted in better behavior intention context, such as further intentions and also, suppliers does not intend to cheat on. In contrast, without commitment, current cooperation will be interrupted. Suppliers may have propensity to complaint or even tendency to use opportunities for cheat on. Hence, we hypothesize the following.

H4 $4_{a, b}$ : The commitment positively affects suppliers' (a) cooperation and (b) long-term orientation.

$H 4_{c}$ : The commitment negatively affects suppliers' opportunism behavior.

\subsection{Conflict versus cooperation, behavioral intention and opportunism}

Existing lower levels of conflict may cause long-term relationship and suppliers prefer to cooperate with firm. Furthermore, it may be resulted in better behavior intention context, such as further intentions and also, suppliers does not intend to cheat on.

In contrast, having high levels of conflict can interrupt current cooperation. Suppliers prefer to seek for new corporation with better relationship and minimum levels of conflict. Also, it may cause complaints or even tendency to use opportunities for cheat on. So, to examine how conflict effects on each cooperation, behavioral intention and opportunism, this research proposes the following hypotheses.

H5 $5_{a, b}$ : The conflict negatively affects suppliers' (a) cooperation and (b) long-term orientation.

H5 $5_{c}$ : The conflict positively affects suppliers' opportunism behaviour.

4.6 Relationship quality as a moderator in relationship between perceived fairness and each of trust, commitment and conflict

Relationship quality can be seen as a moderator in relationship between perceived fairness and each of trust, commitment and conflict in B2B relationships. In fact, the relationship degree between fairness and each of trust, commitment and conflict might not be the same across level of relationship quality. Although the relationship between perceived fairness and trust will be examined in this research, the quality of relationship between a supplier and its firm has impact on the perceived fairness-trust relationship. Poor relationship quality has 
greater impact on perceived fairness-trust relationship. Like trust, I develop same hypotheses for each of commitment and conflict. Thus, I hypothesize the following.

$H 6_{a, b, c}$ : Relationship quality has a moderating role on the relation between suppliers' perceived fairness and each of (a) trust, (b) commitment and (c) cooperation.

\section{Summary}

Studying the effects of having different strategies in a business relationship, perceived fairness and its relationship with eight indexes is considered in this research. First, the related literature is completely reviewed and then a conceptual model is developed and the hypotheses are supposed.

Not believing in fairness in the relationship by suppliers may results in losing trust, commitment and conflict between two-parties. Furthermore, the three mentioned elements could have influence on cooperation between suppliers and firm. More conflicts and less trust may cause cooperation interruption and vice versa, or cause different long-term orientation than before toward firm or in some situation show opportunism. Besides, relationship quality effects as a moderator on relationship between perceived fairness and each of trust, commitment and conflict indirectly.

Indeed, the conceptual model takles the behavior of different suppliers versus their firms and used fairness theory as the theoretical grounding for this research. The conceptual model examined the effect of fairness on trust, commitment, and conflict. We suggested examining the impact of these relational characteristics on the long-term orientation, cooperation, and opportunism and finally, and proposed to examine the moderating role of relationship quality on the link between perceived fairness and relational characteristics.

\section{References}

Axelrod, Robert (1984). The Evolution of Cooperation. New York: Basic Books.

Aurier, P., Siadou-Martin, B., (2007). Perceived justice and consumption experience evaluations: A qualitative and experimental investigation. International Journal of Service Industry Management, Vol. 18, No. 5, 450-471.

Bies RJ, Shapiro DL. (1988). Voice and justification: their influence on procedural fairness judgments. Academy of Management Journal 31(3), 676-685.

Bitner, M.J., Booms, B.H. and Tetreault, M.S. (1990). The service encounter: diagnosing favorable and unfavorable incidents. Journal of Marketing, Vol. 54 No. 1, 71-84.

Blau, Peter (1964), Exchange and Power in Social Life. New York: John Wiley \& Sons, Inc.

Bowen, D.E., Gilliland, S.W. and Folger, R. (1999). How being fair with employees spills over to customers. Organizational Dynamics, Vol. 27 No. 3, 7-23.

Bucklin, Louis P. and Sanjit Sengupta (1993). Organizing Successful Co-Marketing Alliances. Journal of Marketing, 57 (April), 32-46.

Cannon, Christain Homburg. (2001). Buyer-Supplier Relationships and Customer Firm Costs. Journal of Marketing, 65 (January), 29-43. 
Cannon, Joseph P., Ravi S. Achrol, and Gregory T. Gundlach (2000), Contracts, Norms, and Plural Form Governance. Journal of the Academy of Marketing Science, 28 (Spring), 180-194.

Clemmer, E.C. and Schneider, B. (1996). Fair service, in Swartz, T.A., Bowen, D.E. and Brown, S.W. (Eds), Advances in Services Marketing and Management.JAI Press, Greenwich, CT, 109-26.

Coleman, James S. (1990), Foundations of Social Theory. Cambridge, MA: The Belknap Press.

Colquitt JA, Conlon DE, Wesson MJ, Porter COLH, Ng KY. (2001). Justice at the millennium: a metaanalytic review of 25 years of organizational justice research. Journal of Applied Psychology 86(3), 425-445.

Crosby, Lawrence A., Kenneth R. Evans, and Deborah Cowles. (1990). Relationship Quality in Services Selling: An Interpersonal Influence Perspective. Journal of Marketing, 54 (July), 68-81.

Deutsch, Morten. (1962), Cooperation and Tust: Some Theorical Notes, "in Nebraska Symposium on Motivation, Marshall R. Jones, ed. Lincoln: University of Nebraska Press, 275-320.

Dwyer, R.F., Oh, S. (1987). Output sector munificence effects on the internal political economy of marketing channels. Journal of Marketing Research 24, 347-358.

Ellis, K.M., Reus, T.H., Lamont. B.T. (2009). The effects of procedural and informational justice in the integration of related acquisitions. Strategic Management Journal Stars mgmt. J., 30, 137-161.

Gaertner, Samuel L., John F. Dovidio, and B.A. Bachman. (1996), Revisiting the Contact Hypothesis: The Induction of a Common Group Identity. International Journal of Intercultural Relations, 20 (Summer-Fall), 271-290.

Gassenheimer and Chris Manolis. (2001). The Influence of Product Customization and Supplier Selection on Future Intentions: The Mediating Effects of Salesperson and Organizational Trust. Journal of Managerial Issues, 13 (Winter), 418-35.

Giffin, Kim. (1967), The Contribution of Studies of Source Credibility to a Theory of Interpersonal Trust in the Communication Process. Psychological Bulletin, 68 (2), 104-120.

Gilliland, David I. and Daniel C. Bello. (2002). Two Sides of Attitudinal Commitment: The Effect of Calculative and Loyalty Commitment on Enforcement Mechanisms in Distribution Channels. Journal of the Academy of Marketing Science, 30 (1), 24-43.

Grayson, Kent and Tim Ambler. (1999), The Dark Side of Long-Term Relationships in Marketing Services. Journal of Marketing Research, 36 (February), 132-141.

Greenberg J. (1987). A taxonomy of organizational justice theories. Academy of Management Review 12(1), 9-22.

Greenberg J. (1993). The social side of fairness: interpersonal and informational classes of organizational justice. In Justice in the Workplace: Approaching Fairness in Human Resource Management, Cropanzano R (ed). Erlbaum: Hillsdale, NJ, 79-103.

Gundlach, Gregory T., Ravi S. Achrol, and John T. Mentzer. (1995), The Structure of Commitment in Exchange. Journal of Marketing, 59 (January), 78-92. 
Gundlach, Gregory T., and Ernest R. Cadotte. (1994). Exchange Interdependence and Interfirm Interaction: Research in a Simulated Channel Setting. Journal of Marketing Research, 31 (November), 516-532.

Ha, J., Jang, S. (2009). Perceived justice in service recovery and behavioral intentions: The role of relationship quality. International Journal of Hospitality management 28, 319-327.

Hamel, Gary. (1991), Competition for Competence and Interpart-ner Learning Within International Strategic Alliances. Strategic Management Journal, 12 (Summer), 83-103.

Hibbard, Jonathan D., Frederic F. Brunel, Rajiv P. Dant, and Dawn Iacobucci. (2001), Does Relationship Marketing Age Well? Business Strategy Review, 12 (4), 29-35.

Heide, Jan B. and George John. (1988), The Role of Dependence Balancing in Safeguarding Transaction-Specific Assets in Conventional Channels. Journal of Marketing, 52 (January), 20-35.

Hocutt, M.A., Chakraborty, G. and Mowen, J.C. (1997). The impact of perceived justice on customer satisfaction and intention to complaint in a service recovery. Advances in Consumer Research, Vol. 24 No. 1, 457-463.

Hoffman, K. D., and Kelley, S. W. (2000). Perceivedjusticeneeds and recoveryevaluation: A contingency approach. European Journal of Marketing, 34(3,4), 418-432.

Holbrook, R.L. and Kulik, C.T. (2001). Customer perceptions of justice in service transactions: the effects of strong and weak ties. Journal of Organizational Behavior, Vol. 22 No. 7, 743-757.

Homans, G.C. (1961). Social Behavior: Its Elementary Forms. New York: Harcourt, Brace \& World.

Homburg, C., \& Fürst, A. (2005). How organizational complaint handling drives customer loyalty: An analysis of the mechanistic and the organic approach. Journal of Marketing, 69(July), 95-114.

Jap, Sandy D. (1999), "Pie Expansion Efforts: Collaboration Processes in Buyer-Supplier Relationships. Journal of Marketing Research, 36 (November), 461-475.

Jap, Sandy D. (2001), "Pie Sharing in Complex Collaborative Contexts. Journal of Marketing Research, 38 (February), 86-99

Jap, Sandy D. and Shankar Ganesan (2000). Control Mechanisms and the Relationship Life Cycle: Implications for Safeguarding Specific Investments and Developing Commitment. Journal of Marketing Research, 37 (May), 227-245.

Jarvelin, A., Lehtinen, U. (1996). Relationship quality in business-to-business service context. In: Edvardsson, B.B., Johnston, S.W., Scheuing, E.E. (Eds.), QUIS 5 advancing service quality: a global perspective. Lethbridge, Canada, 243-254.

John, George. (1984). An Empirical Investigation of Some Antecedents of Opportunism in a Marketing Channel. Journal of Marketing Research (JMR), Aug, Vol. 21 Issue 3, 278-289

Kalwani, U. Manohar and Narakesari Narayandas. (1995), Long- Term Manufacturer-Supplier Relationships: Do They Pay Off for Supplier Firms? Journal of Marketing, 59 (January), 1-16.

Kelley, S.W., Hoffman, K.D., Davis, M.A. (1993). A typology of retail failures and recoveries. Journal of Retailing 69 (4), 429-452. 
Kim, W.G., Cha, Y.M. (2002). Antecedents and consequences of relationship quality in hotel industry. International Journal of Hospitality Management 21, 321-338.

Kumer, Lisa K. Scheer, and Jan-Benedict E.M. Steenkamp. (1995). The Effects of Perceived Interdependence on Dealer Attitudes. Journal of Marketing Research, 32 (August), 348-356.

Lind EA, Tyler TR. (1988). The Social Psychology of Procedural Justice. Plenum Press: New York.

McColl-Kennedy, J.R., Sparks, B.A. (2003). Application of fairness theory to service failures and service recovery. Journal of Service Research 5 (3), 251-266.

MacNeil, Ian. (1980), The New Social Contract. New Haven, CT: Yale University Press.

Mohr, Jakki J., Robert J. Fisher, and John R. Nevin. (1996). Collaborative Communication in Interfirm Relationships: Moderating Effects of Integration and Control. Journal of Marketing, 60 (July), 103-115.

Moorman, Christine, Gerald Zaltman, and Rohit Deshpandé. (1992). Relationships Between Providers and Users of Market Research: The Dynamics of Trust Within and Between Organizations. Journal of Marketing Research, 29 (August), 314-329.

Morgan, Robert M. and Shelby D. Hunt. (1994). The Commitment-Trust Theory of Relationship Marketing. Journal of Marketing, 58 (July), 20-38.

Nooteboom, Bart, Hans Berger, and G. Niels Noorderhaven. (1997). Effects of Trust and Governance on Relational Risk. The Academy of Management Journal, 40 (April), 308-338

Ok, C.H., Back, K.J., Shanklin, C.W. (2005). Modeling roles of service recovery strategy: a relationship-focused view. Journal of Hospitality \& Tourism Research 29 (4), 484-507.

Orilio, W. (2007). Customer defection is bad customer service reflection. Hospitality Industry Report 14, 1-4.

Palmatier, Robert W., Dant, Rajiv P., and Grewal, Dhruv. (2007). A Comparative Longitudinal Analysis of Theoretical Perspectives of Interorganizational Relationship Performance. Journal of Marketing, Vol. 71 (October 2007), 172-194.

Palmatier, Robert W., Dant, Rajiv P., Dhruv Grewal, and Kenneth R. Evans. (2006). Factors Influencing the Effectiveness of Relationship Marketing: A Meta-Analysis. Journal of Marketing, 70 (October), 156-153.

Parkhe, Arvind. (1993). Strategic Alliance Structuring: A Game Theoretic and Transaction Cost Examination of Interfirm Cooperation. Academy of Management Journal, 36 (August), 794-829.

Pruitt, Dean G. (1981). Negotiation Behavior. New York: Academic Press, Inc.

Reichheld, F.F., Sasser Jr., W. E. (1990). Zero defections: quality comes to services. Harvard Business Review 68 (5), 105-111.

Rindfleisch, Aric and Christine Moorman. (2001). The Acquisition and Utilization of Information in New Product Alliances: A Strengthof- Ties Perspective. Journal of Marketing, 65 (April), 1-18.

Rotter, Julian. (1967). A New Scale for the Measurement of Interpersonal Trust. Journal of Personality, 35 (4), 651-665.

Saxby, C.L., Tat, P.K. and Thompson Johansen, J. (2000). Measuring consumer perceptions 
of procedural justice in a complaintt context. The Journal of Consumer Affairs, Vol. 34 No. 2, 204-216.

Schlenker, Barry R., Bob Helm, and James T. Tedeschi. (1973). The Effects of Personality and Situational Variables on Behavioral Trust. Journal of Personality and Social Psychology, 25 (3), 419-427

Schweiger DM, DeNisi AS. (1991). Communication with employees following a merger: a longitudinal field experiment. Academy of Management Journal 34(1), 110-135.

Selnes, Fred, \& Sallis, James. (2003). Promoting Relationship Learning. Journal of Marketing, Vol. 67 (July 2003), 80-95.

Sheaves, D.E., Barnes, J. G. (1996). The fundamentals of relationships: an exploration of the concept to guide marketing implementation. Advances in Services Marketing and Management 5, 215-245.

Smith, A. K., Bolton, R. N., \& Wagner, J. (1999). A model of customersatisfaction with service encountersinvolvingfailure and recovery. Journal of Marketing Research, 2, 356-372.

Steensma H, van Milligen F. (2003). Bases of power, procedural justice outcomes of mergers: the push and pull factors of influence tactics. Journal of Collective Negotiations 30(2), 113-134.

Tax, S.S., Brown, S.W. and Chandrashekaran, M. (1998). Customer evaluations of service complaintt experiences: implications for relationship marketing. Journal of Marketing, Vol. 62 No. 2, 60-76.

Thibaut J, Walker L. (1975). Procedural Justice: A Psychological Analysis. Erlbaum: Hillsdale, $N J$.

Williamson, Oliver E. (1975). Markets and Hierarchies: Analysis and Antitrust Implications. New York: The Free Press.

Wirtz, Jochen, Jeannette Ho PhengTheng, and Paul Patterson. (2003). Revenue Management: Resolving Potential Customer Conflicts. Journal of Revenue \& Pricing Management, 2 (3), 216-226.

Wong, A., Sohal, A. (2002). An examination of the relationship between trust, commitment and relationship quality. International Journal of Retail \& Distribution Management 30 (1), 34-50.

Zaltman, Gerald and Moorman, Christine. (1988). The Role of Personal Trust in the Use of Research. Journal of Advertising Research, 28 (5), 16-24.

\section{Copyright Disclaimer}

Copyright reserved by the author(s).

This article is an open-access article distributed under the terms and conditions of the Creative Commons Attribution license (http://creativecommons.org/licenses/by/3.0/). 
